\title{
DISARRANGING OUR ALBUM: PHOTOGRAPHY AND GENDER
}

\author{
Maria da Luz Correia \& Carla Cerqueira
}

This special issue of the journal Comunicação e Sociedade departed from our desire of intersecting knowledges and exchanging looks, proposing a meeting on the bordercrossing between photography studies and gender studies. In other words, our willingness to consider photography and gender extended a need to think the gaze politically, from the field of communication sciences. In this context, our intent was to consider the network of asymmetries - gender, but also ethnicity, age, geography, culture and society, among others - as well as the complex bundle of ways of doing and undoing gender, which permeate the everyday circulation of images, and finally, that cross the media discourses and the artistic figurations of our contemporary visual culture (Correia \& Cerqueira, 2017). This need, already at work in the critical perspective of the Frankfurt School philosopher Walter Benjamin, would have been reinforced, since the second half of the $20^{\text {th }}$ century, by different disciplinary traditions, such as structuralism (Foucault, 1975) cultural studies, psychoanalysis, visual culture studies (Berger, 1972, Mitchell, 2002, Mulvey, 1989, Shoat \& Stam, 2006), the french contemporary thought of philosophers like Georges Didi-Huberman (2017) and Jacques Rancière (2008), and of course, the feminist studies, namely post-structuralist and queer (Butler, 1990; De Lauretis, 1987, 1991) and postcolonial (hooks, 1984; Spivak, 1985).

In an editorial process in which more than thirty articles were submitted to doubleblind peer review, we sought to select and organize the different contributions accepted by the reviewers', just like someone who organises and disorganises a collection of photographs, arranging and re-arranging the objects and the problems that appear in this "indisciplined" horizon of photography and gender (Mitchell, 1995; Rancière, 2006; Correia, 2013). Hence, the theoretical frame is already vast in the specific intersection of photography and gender (Alloula, 2001; Friedewald, 2014; Didi-Huberman, 2012; Sullivan \& Janis, 1990; Rosenblum 1994; Humm 2002; Raymond, 2017; Salomon-Godeau, 2017). Likewise, in the more general cross-referencing of media, art and gender, references go beyond any exhaustive enumeration effort. Concentrating on the communication sciences field, and exemplarily in the Portuguese context, the study of media and culture has been profusely filtered by a feminist lens that reveals its dazzling stereotypes, binarisms and exclusions, but which also exposes its trembling breaches of resistance, ambiguity and dialogue (Álvares, 2012; Cabrera et al., 2016; Cascais, 2014; Cerqueira \& Cabecinhas, 2015; Cerqueira et al., 2016; Cerqueira \& Magalhães, 2017; Martins et al., 2015; PintoCoelho \& Mota-Ribeiro, 2012; Santos et al., 2015; Silveirinha, 2015).

This prolix research in the border-crossing of media and gender is not thus a surprising fact, when we think that the origins of communication theory, linked to the

'We are sincerely grateful to all the reviewers of this special issue of Comunicação e Sociedade. Without their contribution, the volume could not be edited. 
emergence of photography, cinema, radio and other means of communication, in the first decades of the $20^{\text {th }}$ century, were also soon connected, by the forerunners of both critical perspective and bureaucratic tradition, to the study of the relations of power and ideological domination operating in the media. From the moment Walter Benjamin (2012) stated the photography and cinema connection to fascism and to revolution to the days of the Web and the digital, of globalization and consumption, the everyday media and culture production have been indeed entangled in a labyrinth of clichés and counter-clichés whose extent and complexity reinforce the necessity of giving continuity to a resistance thought, that locates communication in the interstices of technological, cultural and political questions.

We assume that to think photography through a feminist gaze today goes along with an epistemological stance of resistance, which clearly underlines its political dimension. Thus, we do not only problematize gender inequalities. In a first axis, particularly inspired by the intersectionality approach (Crenshaw, 1991; Knapp, 2005; Oliveira, 2010; Cerqueira \& Magalhães, 2017), we question other types of discrimination - ethnicity, race, age, sexual orientation, class and culture, among others. In a second axis, in a position influenced by the assumptions of the queer approach (Butler, 1990; Oliveira et al, 2009), we do not conform with the old sex and gender dualisms (woman, man, female, male...) rather seeking the hybridity figure as a principle of ambiguity which may extend to other spheres of experience, society and culture.

By proposing a call for papers that would cross photography and gender, we intended, at first, to revolve, from a feminist perspective, the mechanisms of sexism, but also of racism, ethnocentrism, classism, of ageism, of homophobia, among others. These oppressions have been filling in the pages of the history of photography as well as the fragments of contemporary visual culture, whether they come from the sphere of art and/or the sphere of media. In a second moment, we also wanted to interrogate the category of the feminine and the woman (and by contrast, that of the masculine and the man), which, like other binary and essentialised categories of the individuals and their places of belonging (like orient and occident, white and black, dominant and dominated, central and peripheral, intellectual and popular, active and passive, subject and object...), may be more radically thought, through a model of flexibility, complexity and hybridization rather than through a paradigm of rigidity, simplicity and separation.

The article that opens this special issue - "Can there be a feminist aesthetic?" by Claire Raymond - and the interview to Ruth Rosengarten, that closes it, dedicate themselves, to a great extent, to this double effort by problematizing the complexity of this space. Claire Raymond describes the project of a feminist history of photography and a history of feminist photography as a space of social risk and intellectual discomfort, but also as the only place of aesthetic possibility, and political opportunity for a rearrangement of the visible which may resist oppression, from a culturally situated position, according to what Rich would call a location politics (Rich, 2003). Likewise, the artist, curator and researcher Ruth Rosengarten, revisiting one of her earliest essays, dated from the 1980 s (Rosengarten, 1988) and dedicated to photography and feminism, underlines the 
elasticity of feminist photographic practice, which does not conform to the old binarisms (not only related to the gender categories but also to cultural ones). She acknowledges feminism as a "liberatory practice", marked by density and complexity, that "has lent an enabling discourse to other cultural spheres".

The space of a critical history of photography unveiled by Claire Raymond and Ruth Rosengarten is still prolonged by the initial group of articles that, having in common, among other aspects, the social marker of geography, is dedicated to a review of the history of photography in the Portuguese context. In these texts, as well as in the review that Joana Bicacro dedicates to the book Fotogramas edited by Margarida Medeiros, the history of Portuguese photography - which, must be said, has already counted on the most diverse efforts of historical research and critical deepening, in recent years (Sena, 1998; Pinheiro, 2006; Araújo, 2008; Baptista, 2010; Vicente, 2014; Marques, 2016) - is deepened, having its political dimension strengthened. António Fernando Cascais problematizes the stabilization of a binary polarity of sexes in the medical photography of hermaphroditism, carried out in Portugal between the middle of the $19^{\text {th }}$ century and the decades of 1930-1940. On the other hand, Teresa Mendes Flores questions the persistent invisibility of female photographic production in the Portuguese context, and interrogates the status of women amateur photographers during the turn from the 19th to the $2 \mathrm{O}^{\text {th }}$ century, focusing on the case of the Portuguese queen Maria Pia de Sabóia (18471911). Finally, Lorena Travassos inquires the persevering figuration of the colonial body in the Portuguese photographic representations of Brazilian woman. This inquiry is based on a retrospective history of colonial photography and a comparison with the work of the contemporary Portuguese male photographers André Cepeda and Miguel Valle de Figueiredo.

Although we do not have the opportunity for a differentiated analysis of the several studies that have been giving visibility to the women as artists (Nochlin, 1988; Pollock, 1987), and as photographers (Sullivan \& Janis, 1990; Rosenblum, 1994; Humm, 2002; Friedewald, 2014; Raymond, 2017; Salomon-Godeau, 2017) ${ }^{2}$, we can state that considering them in this special issue is not exempt from a political questioning of the feminist aesthetic, capable of crossing gender inequalities with other axes of oppression, these being looked at in a multi-determined way (Cerqueira \& Magalhães, 2017). This perspective of an intersectional questioning of a feminist aesthetic is also clearly expressed by the last four articles of our thematic dossier, as well as by the interview of Helena Ferreira to the Spanish photographer Sandra Barillaro.

The interview with Sandra Barillaro reveals her trajectory as a female photographer who uses her lens as activism to give visibility to groups that are usually invisible, such as Palestine, highlighting the asymmetries of women's experiences in this specific context.

\footnotetext{
${ }^{2}$ It should be noted that, not only in the academic sphere but also in the arts and the cinema, recent efforts have been made to retell the history of photography, giving emphasis to the singularities and differences of feminine photographic production, which has persistently been relegated either to invisibility or to the amorphous and secondary category of margins and peripheries. In the context of gender inequalities, the documentary Objectif Femmes by Manuelle Blanc and Julie Martinovic (2015), and the exhibition "Qui a peur des femmes photographes?" (held the same year at Musée d'Orsay and Musée de l'Orangerie in Paris) are worth mentioning (Galifot et al, 2015).
} 
Ângela Marques and Angie Biondi think upon the political-aesthetic contribution of the Mexican artist Teresa Margolles to the establishment of a common space, through the figuration of vulnerability modes that would inform resistance modes. Similarly, Olga Wanderley acknowledges a political dimension in the earth-body-works of the CubanAmerican artist Ana Mendieta, which associate photography and performance. Those works assume, in particular, a denial of fixed identities - ethnic and gender - within the hegemonic discourses of power. In "Forget Bárbara Virgínia? A forerunner filmmaker between Portugal and Brazil", Paula Sequeiros and Luísa Sequeira resist the memory erasure of the pioneer Portuguese filmmaker, through a social biography of Barbara Virginia's family life and artistic activity, in an approach that crosses gender, class, profession and culture inequalities. Finally, Maggie Humm, who closes this thematic dossier with the essay "Virginia Woolf and photography", focuses on the relationship of Virginia Woolf's work to photographic practice. Keeping an analytical perspective towards Virginia Woof's trajectory, she sustains that her photographs go beyond the family album, questioning material, subjective and cultural identities.

It is also our understanding that one cannot rethink, from a gender perspective, the photographic archive and the space of prolix iconographic flow that it establishes, and which is reinforced today by the advent of the digital and the Web, without having the complex cultural net we refer to unfolded in a no less ambiguous technological mesh. The importance given to the specificity of the photographic medium is clearly stressed by the text of Claire Raymond, by the interview with Ruth Rosengarten and by António Fernando Cascais, in his article on hermaphroditism medical photography3.

Although with distinct perspectives, Claire Raymond, Ruth Rosengarten, and also Antonio Fernando Cascais allude to the ontological particularity of photography that would have its definition in the privilege of indexicality: we refer to the material contiguity of the photographic image with its referent, to its status of partial track of time and of contingent trace of space, which have been exemplarily problematized from Walter Benjamin (2012) to Roland Barthes (1980). It is the indexicality idea that, by pointing at the particular affinity between photography and time, allows Claire Raymond to conclude that all photographs are political. Thus, they reveal, on the one hand, a historical capacity of fragment and, on the other hand, a spectacular capacity of proof. Indeed, in the profusion of photographic observation instruments, in the uninterrupted visual flow of traditional media, in the frantic sharing of images in social networks - whether these are in the sphere of art, entertainment, information or science... -- the differentiating and revolutionary potentialities and the homogenizing and fascist opportunities of photography, stated by Walter Benjamin (2012) at the beginning of the $20^{\text {th }}$ century, are both clearly revealed.

Regarding the photographic medium, António Fernando Cascais's approach to the hermaphroditism medical photography shows us how the indexical paradigm can be put

\footnotetext{
3 This specificity of the photographic medium is also mentioned in the interview of Helena Ferreira to Sandra Barrillaro and in the article "Figurations of the body in the snapshot of digital photojournalism: the non-pose and disfiguration", by Alene Lins, Madalena Oliveira and Luís António Santos, from the "Varia" section of this volume.
} 
at the service of an "authentic iconographic technoscience" which wants to purge the human from his ambivalences, favouring a binary polarity of the sexes. Also, with regard to the digital environment and Web, we can conclude, namely by reading the text of Maria João Faustino, entitled "Digital pygmalion: the symbolic and visual construction of the feminine in CoverDoll online magazine", that this recent technological rupture, alone, does not overpass the dichotomies of feminine and masculine (and similar ones: animal and human, body and mind, nature and culture, biological and technological, organ and artifact...), contrarily to the expectations of the first ciberfeminist speeches. Instead, the spectacularization of the female body and its stereotypies is presently extended in this medium. Equally applying to deconstructing common places and clichés of the feminine in the contemporary media sphere, but in this case, having as object the illustrated magazine Alterosa from the first half of the $20^{\text {th }}$ century, Gelka Barros, in the text "Beautiful and healthy! The women in the pages of Alterosa magazine (1939-1945) during the New State and the Americanization process of Brazil", analyses the corporal pattern, the social conduct, and the conjugal model which the Brazilian woman was confronted with in the period from 1939 to 1945.

In these texts, the first about an online magazine and the second about a photographic magazine, we recognize rupture marks but we also intend to untangle the links of continuity between digital and analogic, old and new media, according to the same ambivalence and complexity principle that has been guiding our point of view, and that, in this context, could namely be expressed by the notion of "remediation" (Bolter \& Grusin, 2000)4. As Claire Raymond and Ruth Rosengarten also suggest in their texts, more explicitly or implicitly, despite the passage from the chemical surface of photography to the digital coded grid, the simplistic and reductive myth of the "photographic truth" raised by the indexical property of photography, which keeps being instigated by media and social networks, has always been destabilized by the staging and montage techniques already applied to photography dated from the beginning of the $19^{\text {th }}$ century (Correia, 2017, Correia, 2016a, Correia, 2016b). Though, from the family albums of the $2 \mathrm{O}^{\text {th }}$ century to the daily selfies of the $21^{\text {st }}$ century, the possibilities of production and circulation of photographs have undeniably blown up, puzzling the realms of technology and culture, photography and gender.

And it is, in the end, in this media and cultural disarrangement, made of ruptures, continuities and metamorphoses, that we re-arrange - temporarily only - the album that, in this issue of Comunicação e Sociedade, passes through, with several hands, voices and gazes, photography and gender.

Translated by Sílvia Correia

\footnotetext{
${ }^{4}$ In this regard, see the contribution of Rodrigo Oliva, José Bidarra and Denise Araújo with their text entitled "Video and storytelling in a digital world: interactions and narratives in videoclips", included in the "Varia" section of this volume.
} 


\section{BIBLIOGRAPHIC REFERENCES}

Alloula, M. (2001). Le Harem Colonial: images d'un sous-erotisme. Paris: Séguier.

Álvares, C. (2012). Discursos do exótico nas revistas femininas: uma análise dos 'outros' do Pós-Feminismo. Comunicação e Sociedade, 21, 151-164.

Araújo, N. B. (2008). Portugal. In J. Hannavy (Ed.), Encyclopedia of Nineteenth-Century Photography Vol. II (pp. 1151-1154). New York: Routledge.

Baptista, P. (2010). A Casa Biel e as suas edições fotográficas no Portugal de Oitocentos. Lisbon: Edições Colibri.

Barthes, R. (1980). La chambre Claire. Note sur la photographie. Paris: Éditions de l'Étoile Gallimard Le Seuil. Benjamin, W. (2012). Sobre Arte, Técnica, Linguagem e Política. Lisbon: Relógio d’Água.

Berger, J. (1972). Ways of seeing. London: Penguin Books.

Bolter, J. D. \& Grusin, R. (2000). Remediation: understanding new media. Cambridge: MIT Press.

Butler, J. (1990). Gender Trouble: Feminism and the Subversion of Identity. New York: Routledge.

Cabrera, A.; Martins, C.; Batista, C.; Mata, M. J. \& Flores, T. M. (2016). Política no Feminino. Lisbon: Aletheia Editores.

Cascais, A. F. (Ed.) (2004). Indisciplinar a Teoria: Estudos Gays, Lésbicos e Queer. Lisbon: Fenda.

Cerqueira, C. \& Cabecinhas, R. (2015). A cobertura jornalística do Dia Internacional das Mulheres na imprensa portuguesa: mudanças, persistências e reconfigurações. Dossiê. Revista Novos Olhares 4(1), 37-51. Retrieved from http://www.revistas.usp.br/novosolhares/article/view/102209

Cerqueira, C.; Cabecinhas, R. \& Magalhães, S. I. (Eds.) (2016). Gender in focus: (new) trends in media. Braga: Centro de Estudos de Comunicação e Sociedade.

Cerqueira, C. \& Magalhães, S. I. (2017). Ensaio sobre cegueiras: cruzamentos interseccionais e (in) visibilidades nos media. ex aequo, 25, 9-20. doi: 10.22355/exaequo.2017.35.01

Correia, M. L. (2016a). No negativo: morte e fotografia. In M. L. Martins; M. L. Correia; P. B. Vaz \& E. Antunes (Eds), Figurações da morte nos média e na cultura: entre o estranho e o familiar (pp.207-226). Braga: Centro de Estudos de Comunicação e Sociedade.

Correia, M. L. (2016b). The recreational image: from photographic amusements to video games. In J. G. Pinto \& R. Matoso (Eds.), Art and Photography in Media Environments (pp.107-120). Lisbon: Edições Universitárias Lusófonas.

Correia, M. L. \& Cerqueira, C. (2017). Pontos de vista. Vista, revista de cultura visual, 1, 7-15. Retrieved from http://vista.sopcom.pt/ficheiros/20170519-7_15.pdf

Correia, M. L. (2017). Contra-retratos: a subversão do grão fotográfico. Revista de Comunicação e Linguagens, 47, $137-156$.

Crenshaw, K. (1991). Mapping the Margins: Intersectionality, Identity, Politics and Violence against Women of Color. Stanford Law Review, 43(6),1241-1299. doi: 10.2307/1229039

De Lauretis, T. (1987). Technologies of gender: Essays on theory, film and fiction. Bloomington: Indiana University Press.

De Lauretis, T. (1991). Queer Theory: Lesbian and Gay Sexualities: an Introduction. Differences, 3(2), iii-viii. 
Didi-Huberman, G. (2017). Povos expostos, povos figurantes. Vista revista de cultura visual, 1, 16-31. Retrieved from http://vista.sopcom.pt/ficheiros/20170519-16_31.pdf

Friedewald, B. (2014). Women Photographers: From Julia Margaret Cameron to Cindy Sherman. London: Prestel.

Foucault, M. (1975). Surveiller et punir, naissance de la prison. Paris: Éditions Gallimard.

Galifot, T.; Pohlmann, U. \& Robert, M. (Eds.) (2015). Qui a peur des femmes photographes? 1839-1945. Paris: Musée D'Orsay e Hazan.

hooks, B. (1984). Feminist Theory: From Margin to Center. Boston: South End Press.

Humm, M. (2002). Modernist Women and Visual Cultures: Virginia Woolf, Vanessa Bell, Photography, and Cinema. Nova Jersey: Rutgers University Press.

Knapp, G. (2005). Race, Class, Gender: Reclaiming Baggage in Fast Travelling Theories. European Journal of Women's Studies, 12, 249-265.

Marques, S. L. (2016). Fotografia-História, o pensamento em imagens. Contributos para a leitura de 'História da Imagem Fotográfica em Portugal, 1839-1997' como um hiperdocumento. Doctoral Thesis, Universidade Nova de Lisboa, Lisboa, Portugal.

Martins, M.; Baptista, M. M.; Pinto-Coelho, Z. \& Maia, S. (2015) (Eds). Género: contributos para uma compreensão efetiva das mudanças. Revista Lusófona de Estudos Culturais / Lusophone Journal of Cultural Studies, 3(1). Retrieved from http://rlec.pt/index.php/rlec/issue/view/5/showToc

Mitchell, W. T. J. (1995). Interdisciplinarity and Visual Culture. Art Bulletin, LXXVII(4), 540-544.

Mitchell, W. J. T. (2002). Showing seeing: a critique of visual culture. Journal of Visual Culture, 1(2), 165- 181.

Mulvey, L. (1989). Visual and Other Pleasures. Bloomington and Indianapolis: Indiana University Press.

Nochlin, L. (1988). Women, Art and Power, and Other Essays. New York: Harper\&Row.

Oliveira, J. M.; Pinto, P.; Pena, C. \& Costa, C. G. (2009). Feminismos queer: disjunções, articulações e ressignificações. ex aequo, 20, 13-27. Retrived from http://www.scielo.mec.pt/pdf/aeq/n20/n20ao3.pdf

Oliveira, J. M. (2010). Os feminismos habitam espaços hifenizados - A localização e interseccionalidade dos saberes feministas. ex aequo, 22, 25-39. Retrived from http://www.scielo.mec.pt/scielo.php?script=sci_ar ttext\&pid=S0874-55602010000200005

Pinheiro, N. A. (2006). O Teatro da sociedade: fotografia e representação social no espaço privado e no público. Lisbon: Centro de Estudos de História Contemporânea Portuguesa.

Pinto-Coelho, Z. \& Mota-Ribeiro, S. (2012). Género e Heterossexualidade - Discursos e Imagens na Publicidade e nos Media, Vol.21. Comunicação e Sociedade, 11, 175-184. doi: 10.17231/ comsoc.11(2007).1140

Pollock, G. (1987). Vision and Difference. Feminism, Feminity and Histories of Art. Massachussets: Methuen Publishing.

Rancière, J. (2006). Thinking between disciplines: an aesthetics of knowledge. Victoria: The University of Melbourne. Retrived from http://www.parrhesiajournal.org/parrhesiao1/parrhesiao1_ranciere.pdf

Rancière, J. (2008). Le spectateur emancipé. Paris: La Fabrique Éditions.

Raymond, C. (2017). Women Photographers and Feminist Aesthetic. London: Routledge. 
Rich, A. (2003). Notes Toward a Politics of Location. In C. McCann \& S. Kim (Eds.), Feminist Local and Global Theory Reader (pp. 247-259). New York: Routledge.

Rosenblum, N. (1994). History of Women Photographers. New York: Abbeville Press.

Rosengarten, R. (1988). Pontos de vista: Fotografia e Feminismo no contexto do Pós-modernismo. Revista de Comunicação e Linguagens, 6/7, 213-225.

Salomon-Godeau, A. (2017). Photography after Photography: Gender, Genre, History. New York: Duke University Press.

Santos, A.; Cerqueira, C. \& Cabecinhas, R. (2015). Entre a norma e a exceção: assimetrias de género nas newsmagazines portuguesas. Comunicação e Sociedade, 27, 437-455. doi: 10.17231/comsoc.27(2015).2111

Sena, A. (1998). História da imagem fotográfica em Portugal-1839-1997. Porto: Porto Editora.

Shohat, E. \& Stam, R. (2006). Crítica da imagem eurocêntrica. São Paulo: Cosac Naify.

Silveirinha, M. J. (2015). Da Cidade do México à Aldeia Transnacional, ou das velhas e novas desigualdades comunicacionais de género. Media QJ Jornalismo, 25(14).

Spivak, G. (1985). Can the Subaltern Speak? Speculations on Widow Sacrifice. Wedge, 7(8), 120-130.

Sullivan, C. \& Janis, E. P. (1990). Women Photographers. New York: Harry N. Abrams Edition.

Vicente, F. L. (2014). O Império da Visão. Fotografia no Contexto Colonial Português (186o-196o). Lisbon: Edições 70.

\section{FILMOGRAPHY}

Blanc, M. \& Martinovic, J. (2015). Objectif femmes. France: Camera Lucida Productions.

\section{BiographicAL Notes}

Maria da Luz Correia is an Assistant Professor in the Department of Languages, Literatures and Cultures, in the University of Azores and a researcher at Communication and Society Research Centre (CECS). She holds a PHD in Communication Sciences, from the University of Minho and in Sociology, from the Université Paris Descartes - Sorbonne. She has published on the fields of visual culture, image theory and photography.

Email: maria.If.correia@uac.pt

Universidade dos Açores, Faculdade de Ciêncais Sociais e Humanas, Ladeira da Mãe de Deus, 9501-855 Ponta Delgada, Portugal

Carla Cerqueira holds a PhD in Communication Sciences (specialization in Communication Psychology). She is a Postdoctoral Grantee in Communication Sciences (SFRH/BPD/86198/2012) at the Communication and Society Research Centre (CECS), University of Minho, Portugal, and a visiting researcher at the Department of Media, Communication and Culture, Autonomous University of Barcelona, Spain; and at the 
Department of Social Sciences, Erasmus University of Rotterdam, Netherlands. She is also an Assistant Professor at Lusophone University of Porto, Portugal. Author of several books, book chapters and papers in scientific journals, her research interests include gender, feminisms, NGOs and media studies.

Email: carlaprec3@gmail.com

Centro de Estudos de Comunicação e Sociedade, Universidade do Minho, Campus de Gualtar, 4710-057 Braga, Portugal 